\title{
The Story of Victimhood-Basic Income Recipients Positioning Street-Level Bureaucracies
}

\author{
Sari Mäki \\ Department of Economics and Management, University of Helsinki, Helsinki, Finland \\ Email: sari.maki@helsinki.fi
}

Received December $3^{\text {rd }}$, 2012; revised January 10 ${ }^{\text {th }}, 2013$; accepted January 22 $2^{\text {nd }}, 2013$

\begin{abstract}
The article focuses on how people living on basic income benefits position street-level bureaucrats in their speech. The research material consists of 15 unstructured interviews gathered mainly in association for unemployed. Analysis is done in the context of positioning theory. Participants always have moral positions in discussion and with these positions they have different rights and duties to say certain things. Interviewees' speech and especially the word choice reflect on known story-line and interviewees' position in it. There is always a new story-line for each shift in interviewees taken or given position. Basic income recipients position street-level bureaucrats as inadequate, disciplining and unpredictable. I interpret that these given positions enable a shift of autonomy from recipients to street-level bureaucrats. Hence the given positioning reflects the story-line of victimhood.
\end{abstract}

Keywords: Basic Income; Street-Level Bureaucracy; Positioning Theory; Victimhood

\section{Introduction}

"They blame us for our unemployment. I think there should instead be pastoral sent to employees and Employment and Economic Development Office to employ us full-time.” These words of an interviewed basic income benefits recipient give insight to the lives of unprivileged in Finland. These words are talking back to the discourse where to be poor or unprivileged is to receive social positioning in which one is easily blamed for refusing better for themselves. It is as if the poor doesn't want jobs and they get themselves pregnant for the benefits. They are clever and they tell lies. Like the above excerpt reveals people living on a basic income benefits consider the situation differently. However for the greater public former beliefs are easier to believe than considering poverty stemming from unfair structure.

To form a larger view on the matter requires it to listen to people who know what it is like to live on a basic income benefits. These people have many stories to tell and after listening them, two aspects have become clear. The first story told portrays the interviewed as active and inventive people while the second story make them as victims of powerful forces. I have unfolded the matters concerning the first story elsewhere (Mäki, 2011) so in this article I concentrate on the story that comes after. The second story is almost all about interviewees' relationship with street-level bureaucracy. Basic income benefits recipients have more or less close contact to authorities. Those encounters are where their identity is reshaped. Within these encounters personal life stories are told and come to life in the privacy of an administration desk (Dubois, 2010: p. 2). Experiences of encounters are then shared with and retold to friends and relatives and to me as a researcher. To be able to tell and to be listened is to have deference as a human being.

Street-level bureaucracy is often studied from the bureaucrats' point of view. On the contrary, my aim is to give insight to lives and experiences of clients of those bureaucracies. Al- though most of the studies concerns bureaucrats, there are also research especially in housing and healthcare to be found from the clients' point of view (see Fotaki, 2011; Teater, 2010; Jost, Levitt, \& Porcu, 2010; Darbyshire et al., 2006). Clients perspective is also found in studies of identity construction in relation to welfare services (Juhila \& Abrams, 2011; Miller, 2011; Solberg, 2011; Virokannas, 2011), of crime and victimization (Kohm, 2006), of social worker and welfare recipient attitudes (Bullock, 2004), the poor in general (Peel, 2003) as well as consumers of welfare reform (Kraft \& Bush, 1998). All these studies share understanding of the need for the possibility to ordinary people to have a say in matters concerning their lives, moreover, to expand knowledge for improving the existing policies.

In this article my aim is to show how people living on a basic income benefits position street-level bureaucrats they are in contact with. Interviewed people are clients of several street-level bureaucracies including The Social Insurance Institution of Finland, Employment and Economic Development Office, Courts, Social Services as well as Municipal Health Services. Whether the clients are satisfied for the services or not is rarely asked.

Like Lipsky (1980: p. 54) puts it "the poorer the person the more he or she is likely to be the nonvoluntary client of not only one but several street-level bureaucracies”. Being a nonvoluntary means that a person is not able to decide what kind of treatment he or she is getting. And when it comes down to complaining about the treatment one is easily replaced with someone who is willing to accept the cost of seeking the treatment.

I analyze the talk of interviewed people in the context of positioning theory. According to the positioning theory "not only what we do but also what we can do is restricted by the rights, duties and obligations we acquire, assume or which are imposed upon us in the concrete social contexts of everyday life" 
(Harré \& van Langenhove, 1999: p. 4). Davies and Harré (1990: p. 61) note that to see one in a certain position requires it a certain perception of story line. The story lines changes between basic income receivers interviewed and how they appear to public. These changes can be seen when interviewed people are refusing certain positioning. Perception of the differentiation in story lines also reflects the boundaries in which to act.

For interpretation of story-lines and to locate the moral order of living on a basic income benefits in a welfare society I have gone through questions like what rights or opportunities interviewees are trying to gain by positioning this way or what kind of duties and restrictions these taken and given positions reflect? I interpret that the following positions interviewees give to the street-level bureaucrats are all constructing a story-line of victimhood. The lack of money and living on a basic income benefits makes the interviewees depend on authorities. Dependency eliminates the recipients' autonomy and shifts the power to rule to the authorities. That is when the victimhood shows. Authorities don't always find ways of helping the basic income receivers and that raises anger.

I have constructed the article following way. At first I give a short outline of Finnish basic income security system. And then move on to presenting my research material and analysis. Then I proceed to the positioning of street-level bureaucrats: inadequacy, discipline and unpredictability. I end the article with discussion of the story-line of victimhood.

\section{Public Support of Basic Income Security Recipients}

The Finnish public support concerning basic income security recipients consists of state regulated income support including employment services and municipally led social and health services, social work and social assistance. State regulated income support is claimed from The Social Insurance Institute of Finland (KELA) which street-level workers are advising clients but are not able to use discretion on decisions of benefits applications. Basic unemployment benefits are also paid through KELA. To be eligible for unemployment benefits one has to be part of employment services run by Employment and Economic Development Offices. The difference to street-level workers of KELA the clerks in Employment and Economic Development Offices are able to use at least some discretion towards the clients. Possibility to use discretion in street-level work increases in municipally led social- and health services as well as in social work and social assistance.

Former studies about the social security system and ideas about what constitutes an adequate standard of living (Adequacy of basic income benefits 2011, Lehtinen, Raijas, Varjonen, \& Aalto, 2010, 2011; Juntunen, Grönlund, Hiilamo, 2006; Aatola \& Viinisalo, 1999; Forma, Heikkilä, \& Keskitalo, 1999; Kosunen, 1999) share a common understanding that the level of Finnish basic income support, including housing allowance, paid by KELA is too low. The Finnish Constitution states that in situations where income support is needed the income shouldn't be based on the last resort form of income support, social assistance, owing to the fact that the benefit is very disciplining and the application process is very humiliating (Sakslin, 2008: pp. 34-38). Nevertheless in many cases social assistance complements the income of basic unemployment allowance and labor market subsidy receivers (Adequacy of Basic Income Benefits, 2011; Honkanen, 2009).
This has also been acknowledged by the Committee for Comprehensive Reform for Social Protection (SATA). The committee's main aims were to ensure that the option of taking employment is always worthwhile, to reduce poverty levels and to safeguard sufficient minimum income levels in all life situations. Given the current economic situation, Finnish political circles have not been prepared to accept or implement all the improvements that SATA raised (Lehto, 2009). The current level of Finnish basic income benefits can be seen in Table 1.

Purpose of the Labour Market Subsidy is to provide financial assistance for unemployed job seekers who enter the labour market for the first time or otherwise have no recent work experience as well as long-term unemployed persons who have exhausted their 500-day eligibility for the basic or earningsrelated unemployment allowance. Social assistance is a last resort form of income security. Municipalities pay means-tested social assistance when the income and resources of an individual or family are insufficient to cover daily expenses.

The level of basic income benefits excluding higher education study grant has been raised by 100 euro beginning of the year 2012. Nevertheless those households receiving some of the basic income benefits together with the social assistance find their income increasing only about 30 euro. It has been calculated that the current increase in basic income benefits raises them to the level as they were in the beginning of 1990s. When relating the basic income benefits to the general income level it is revealed that the level of current increase is not enough to reduce the gap between them (Honkanen \& Tervola, 2012).

\section{Research Material and Analysis}

My research material consist of 15 unstructured basic income receivers' interviews each lasting approximately one hour. I gathered the data in the Helsinki Association for the Unemployed, in coffee shops and in the interviewees' homes between August 2009 and April 2010.

The interviewees include eight women and seven men aged from 21 years to 65 years. Seven of them are living alone, three are single parents, and three are in relationships - two of which have children-and two interviewees live with their parents. Nine of them are recipients of either basic unemployment allowance or labor market subsidy, three of them receive a national pension, two of them receive the parental allowance and one of them receive a higher education study grant. Most of the interviewees' income is supplemented with social assistance

Table 1.

Level of Finnish basic income benefits in 2013 (The Social Insurance Institution of Finland).

\begin{tabular}{cc}
\hline Basic income benefit & Level/Month \\
\hline National pension & $732 €$ \\
Basic unemployment allowance & $698 €$ \\
Labour market subsidy & $698 €$ \\
Sickness and parental allowance & $511 €$ \\
Social assistance, person living alone & $477 €$ \\
Child home care allowance & $336 €$ \\
Higher education study grant and housing & $298 €+201 €$ \\
\hline
\end{tabular}


and general housing allowance. The themes discussed in the interviews were family, consumption, money, health, work, social security and society.

I analyze the research material in the context of positioning theory. Participants always have moral positions in discussion and with these positions they have different rights and duties to say certain things. People living on a basic income benefits are controlled by authorities and they don't have possibility to influence the decisions authorities make. On the other hand while interviewed by researcher basic income receivers are encouraged to speak freely about their feelings. The research situation enables with the positioning theory a ground for revealing society's power relations. It can be said with words of Pöysä (2010: p. 169) "positioning of self in stories told by self is a central mode of autonomy. Possibility for autonomy through stories makes the unjust experiences seen in a way the self wants them to be seen".

Interviewees' speech and especially the word choice reflect on known story-line and interviewees' position in it. There is always a new story-line for each shift in interviewees taken or given position (van Langenhove \& Harre, 1999). For this article I have organized the research material by reading transcribed interviews and placing interviewees' utterances in to themes i.e. positions. I concentrate on those utterances where interviewees position themselves in relation to street-level bureaucrats. In the article I will show according to what kind of utterances I have constructed these three positions and how does the story-line unfold.

I analyze how interviewees are in their discourse making their own or others actions intelligible by referring either to known moral order or specific personal features (van Langenhove \& Harré, 1999). For example street-level bureaucrats are morally expected to have the power to help people in need. When this role isn't fulfilled morally as expected the emphasis is placed on personal positioning. This is the case when recipient of social assistance isn't getting what she thinks she is entitled to. She might start to make the act of refusal intelligible by accusing personal matters of oneself or one giving the refusal (street-level bureaucrat). These kinds of personal statements while positioning street-level bureaucrats can reveal several inconsistencies in welfare state structure.

Owing to the constructivist nature of positioning theory I have interpreted positions in a way that Alvesson \& Karreman (2000: p. 1137) calls a long-range/autonomous discourse. The question of the long-range/autonomous discourse is whether specific statements from research material can be related to other, similar statements on the topic of for example victimhood. Whether the given statements are true or false is not an issue. I am interested how the story-line of victimhood can be constructed by the positioning basic income benefits receivers' do in their speech and what kind of moral order the story-line reflect. I am also interested whether similar construction of story-line can be found in previous studies of Dubois (2010), Peel (2003), Lamb (1999) and Lipsky (1980). My intention is not to give any amendments but instead I am following Hackings (1999: p. 20) presentation of unmasking. According to unmasking (Mannheim, 1925, 1952: p. 140) I am not seeking to repeal ideas but "to undermine them by exposing the function they serve” (Hacking, 1999: p. 20).

\section{Positioning Street-Level Bureaucrats}

There is a lot of talk about street-level bureaucracies among interviewees. The interviewees' frame of reference is mostly experiential. The injustices' experienced are shared with researcher. Experience of inadequacy is generating the most of the talk of street-level bureaucrats. However discipline and unpredictability of street-level bureaucracy are also raised in interviewees talk. For my study and for this article the talk of street-level bureaucracy encompasses institutions as The Social Insurance Institution of Finland, Employment and Economic Development Office, Courts, Social Services as well as Municipal Health Services. The excerpts from the research material presented here are anonymised. However the context of the excerpts has been maintained, i.e. which institution the interviewee is referring to in his/her speech.

\section{Three-Pronged Inadequacy}

Removal of unemployment, the level of basic income benefits and the services provided are all considered inadequate by interviewed recipients. These three aspects brought up discursively construct the inadequate position. To begin with the interviewees think that street-level bureaucrats don't provide enough help for getting employment. This is addressed to authorities of Employment and Economic Development Office. The most disappointing part is the labour market training which almost every interviewee brought up.

Employment and Economic Development Office internet pages state that "the objective of labour market training is to improve the participants' chances of finding work. Labour market training can also be preparatory, including training, providing guidance towards an occupational field and improving job search capacities, IT skills and language training for immigrants. Labour market training also aims to promote the employment of the long-term unemployed, ageing and disabled and to prevent exclusion.” An interviewee reasons his situation as unemployed:

"What would be the use of it? (Labour market training) I am aware of my situation. It is not going to change by taking courses of how to apply jobs. Neither can those clerks help. They are only passing papers back and forth” (Interview 4).

It is commonly shared view among interviewees that labour market training is not the cure for their unemployment. The courses offered are thought not to be valued among employers. It is hard to motivate oneself to take a course which is considered useless in terms of getting a paid employment. The matter in here is not whether the clerk is doing a right thing but that the welfare support system is constructed in a controlling way.

The second aspect of inadequacy is the level of basic income benefits which interviewees think is too low for decent living. Usually the interviewees' basic income benefits are supplemented by general housing allowance and social assistance. Interviewees are also critical about the level of these supplement benefits. General housing allowance has left behind from the housing costs and owing to that the social assistance often supplements the general housing allowance the social assistance is insufficient for all the living costs. This is the case for those who are eligible for social assistance. An interviewee describes the situation:

"I guess that almost every municipality in Finland has reduced granting at least the preventive social assistance. It is terrible fight for your rights in there (in social services)" (Interview 13).

Inadequacy of the level of basic income is associated with 
Municipal Health Services which resources are seen to be too low. Interviewees view that it is very hard to get treatment from public health services. Waiting time for seeing a doctor is very long and the treatments are too short-term as well as inefficient particularly with the mental health problems. Interviewees have experiences where doctors favour medical treatments over trying to see patient as a whole.

"I went to the doctors because of continuing fever. They did run several blood tests but found nothing. They agreed with me that something was wrong but suggested me to go home and book another appointment later on if I felt like it. It is as if they don't see patient as a whole: they don't inquire and they don't let the patient tell them about their life. It is very clinical procedure” (Interview 15).

All recipients aren't ready for that kind of procedure and they easily become considered difficult customers. Difficult customers have more difficulties to get served and they become angry and threatening as is the case following.

"When they are cutting down services there are 1500 mental patients left without treatment in this city. I send an email last week for the head of social and health services that have you forgotten what happened in Jokela or Kauhajoki. I asked that who is taking the responsibility if something happens. The head promised to find out and get back to me. In the meantime I was given short continuation in mental therapy" (Interview 13).

In addition to threatening street-level authorities some interviewees threatens themselves. An interviewee reasons his selfthreatening actions

"I had to start talking about suicide. As a single man I am not getting any help but as I am a single parent they have to think about what my suicide would do for my children. The resources for mental health care are so weak that they only gave me one appointment with the doctor. One appointment” (Interview 8).

It seems like capability of interviewees turns out to be, when set against low resources of social and health care, aggressiveness or illegal matters towards the street-level bureaucracies or oneself. But if we can get over the angry matters revealed here we are able to reason the structure of this functioning. Dubois (2010: p. 166) argues that the recipients violence can be a last resort for people who are facing difficult social situations as extreme poverty and isolation. That is the case also when the recipient is threatening oneself. When raising his voice and threatening reception agent or directly contacting manager the recipient hopes for more favorable treatment (Dubois, 2010: p. 167). Lipsky (1980: p. 59) notes that people come to street-level bureaucracies as individuals with different life histories but in their encounters with bureaucracies they are treated with and put in to only a few categories. With these encounters recipients lose their uniqueness and violence is then a way for self-assertion (also Dubois, 2010: p. 167).

The inadequacy of services provided is the third factor. Interviewees see that street-level bureaucrats in many cases should have told more about matters concerning the service process.

"I inquired well in advance about what I have to do in terms of applying the unemployment benefits. I think they should have told me that the decision is going to take a long time. It took a month and two weeks to get the decision" (Interview 15).

The experience about long decision times is common among all interviewees. There are also cases where an interviewee hasn't got help at all. These are often complex cases which require cooperation between ranges of street-level bureaucrats.

"I am continuously trying to think who would be the right person to help me. You would think that there was someone in this country. They are only juggling me around. I have never received any proper help. I think it is because this society has become so short-sighted" (Interview 13).

Even though complex problems are hard to deal there are also problems with getting common appointments to social workers. The need of social assistance is not a cause for being able to see social worker. Some of the interviewed social assistance recipients think they should automatically be eligible for social work and others think they just need the money. It seems that being able to acknowledge these divers needs would help the people in need.

"They sent me a letter which stated that clerks in social services don't have discretion. Clerks only routinely go through applications and makes computer-aided decisions according to certain standards. You would think that these clerks had enough wisdom to get in contact with the customer who seems to be in need for social work. That would be good service” (Interview 11).

Dubois (2010: pp. 139-140) presents similar results in his study on encounters with the bureaucrat and the poor. According to his research cases where recipient feel that the computer decides are not uncommon.

\section{Disciplining Procedures}

Feeling disciplined is about having to do something unreasonable in order to receive public support. In the former chapter about inadequacy interviewees thought that the clerks don't have enough discretion when it comes to the social work. However interviewees think that individual authorities in Employment and Economic Development Office are able to use too much discretion.

"I just got unemployed again and have to find some part-time work because an officer didn't grant subsidized full-time employment for me. The officer used discretion and decided not to grant me. There wasn't an opportunity to complain” (Interview 1).

Part-time work whilst receiving basic income benefits has its downsides. Working two hours a week for example, whilst being essentially unemployed removes the possibility of obtaining a long-term-unemployed status. This means that one is not eligible for the support intended for the long-term-unemployed. Long-term-unemployment support is mainly implemented by subsidized full-time employment. The interviewees were critical of the fact that under the current social security system one is better off staying at home and doing nothing for 500 days than going out and finding a part-time job. The interviewees think that due to these regulations the system promotes apathy. Those who work part-time in order perhaps to maintain their work skills are in a way punished by the welfare support system for trying to be active.

Another disciplining manner mentioned is street-level bureaucrats' diktats.

"When you are poor or unemployed you don't really get to say what kind of help you would need. The street-level bureaucrats tell you that "look we have done these things like this and listen we do these things like this and you have to bring this and that form and so on" (Interview 8).

There are also experiences of officers who aren't telling all 
the possible options but instead dictating the interviewees to apply unsuitable jobs. Interviewees feel that the street-level bureaucrats blame them for being unemployed and the blame is even worse if recipients aren't aware how basic income system works. Interviewees also feel disciplined owing to the filing of the benefits application information.

"When I have to go to for example Kela (social insurance institute of Finland) and no matter what is my reason to go there they open up my file and for the first half an hour officer reads through the information although that information has got nothing to do with my existing matter. It is frustrating and I am quite sure that these already past matters have effect for the future decisions” (Interview 13).

When the basic income security system is concerned the interviewees think that the bureaucracy is the worst part of it. Bureaucracy appears to make life harder when interviewees either apply for social assistance or have part-time jobs together with benefits.

"I fill the social assistance application every month. Always the same amounts of electric bill, rent and so on. I give them a copy of my lease and other costs monthly. Monthly" (Interview 10).

An interviewee suggests a solution for monthly bureaucratic manner:

"Single-window system would be the best. There wouldn't be any begging for your rights. Social assistance is the worst benefit owing to that you have to present your bank statements and all. For the labor market subsidy you have to present the amount of your income and that's it” (Interview 11).

Monthly repeated bureaucratic control takes the motivation away from part-time job and encourages the recipients to search for alternative ways of coping for example illegal earnings and instant loans (see Mäki, 2011; Autio, Wilska, Kaartinen, \& Lähteenmaa, 2009).

\section{Unpredictable Advice}

Interviewees feel that the basic income security system is unpredictable for several reasons. The interviewees receiving social assistance don't know how much they can earn without a reduction in or loss of their benefits. Interviewees said to me that they haven't received a proper answer for their question about the eligible amount of own earnings whilst living on social assistance. This also exists with basic unemployment benefits and housing allowance. Opacity gets worse with recipients receiving these three benefits simultaneously. Irregularities in the system such as delays, mistakes in calculations and lost documents also cause unpredictability.

"I once received social assistance and it stated in the decision letter that they have granted me 25 euro for other costs. Rather negligible amount. A friend of mine had once received money for his hobby so we thought that these other costs meant that. Well it became clear that there had been a mistake in calculation and social services claimed the money back" (Interview 11).

In addition to the system street-level officers are also a cause for unpredictability. Interviewees have experiences where an officer hasn't been aware of what documents should be included in applying certain benefits. That is the case especially with complex issues where recipient is receiving multiple benefits. Recipients have also been asked to submit unnecessary documents and some necessary documents are lost by officers.
"I received a letter from Social Insurance Institute of Finland saying that treatment of my benefits is almost completed. I started to wonder what it meant and I called to the office and asked about it. The officer couldn't answer me which benefit the completion letter meant. She promised to find out. Still at this day I don't know what benefit that letter was about” (Interview 13).

Dubois (2010: p. 140) also pays attention to administrative letters which according to his research are occasionally incomeprehensible even for those who have a good grasp of administrative language for example reception agents. This kind of letters is often sent automatically and doesn't require any action from the recipient. But like Dubois (2010: p. 140) puts it "these letters often cause recipients to worry" and they either come or phone to the office. These experiences "foster an Orwellian vision of an inhuman institution to which men-including the benefit office agents have to submit” (Dubois, 2010: p. 140).

\section{Victims of the Welfare State?}

Welfare bureaucracy in general is the core of my analysis and how it appears in the lives of clients in relation to streetlevel bureaucracy. Position construction of inadequacy, discipline and unpredictability all derive from interviewees having a close and sustained relationship with street-level bureaucrats. The greater the involvement of the recipient with the streetlevel officer, the more sustained and critical are the implications of the interactions (Lipsky, 1980: p. 66). Interviewed people living with scarce economic resources have to depend on several agencies and they are often bounced from one agency to another. Feelings of dependency, powerlessness, and, deriving from these, anger are everyday life for the interviewees.

Positions of inadequacy, discipline and unpredictability appoint the responsibility of current situation from the recipient to the street-level bureaucrats. Interviewees are reciting these selfvictimizing positions when the bureaucracy is concerned but are at the same time positioning themselves as active job seekers and modest consumers. I interpret this difference in positioning deriving from unfolding story-line of victimhood. Positioning one and the others this way one is able to distance oneself from the system, denouncing it and prove self-affirming (see Dubois, 2010: p. 143). Bureaucracy: the use of discretion of the street-level bureaucrats, local and/or legal enforcement i.e. practices of individual welfare departments as well as the statute of welfare support system influence the clients and how they experience the welfare state. Interviewees are in their speech able to differentiate the bureaucracy into these three aspects but the consequences in action are only seen in the street-level.

It seems that the interviewees are obliged to prove their worth for benefits by choosing between two sides in their speech. It has been argued (Cole, 2007; Lamb, 1999; Minow, 1993) that being a victim forfeits the agency. Minow (1993, 1411) describes that "the victim is helpless, decimated, pathetic, weak, and ignorant. Departing from this script may mean losing whatever entitlements and compassion victim status may afford." She interestingly continues that "fear of losing those benefits may explain why support groups for victims seldom involve challenges to the victim identity itself.” Acknowledging the victim status for oneself is to give up the autonomy for those in control. On the contrary for being a victim and showing some agency is to complicate their status, thus they are not 
real victims and eligible for the benefits. People can be either a victim or an active subject, but not both. (Ronai, 1999: p. 149.)

It might seem according to the positioning introduced in this article that the interviewees are victims yielding the power to the street-level bureaucrats. That is not the whole story since at the same time interviewees are positioning themselves as capable survivors resisting the existing order (Mäki, 2012). By being capable, which is to say frugal and inventive, interviewees show their worth as active not passive members of a society who deserves to be helped. Although seeking capable lifestyle basic income receivers face authorities who control and require obedience in terms of bureaucracy. It seems that the victimhood is imperative part of the basic income recipients' life when it comes to authorities and claiming benefits. This raise a question whether people living on a basic income are accused being passive while the welfare support system is actually forcing to it?

The problematic part is that no matter how they talk and how they want to appear to the public interviewed people are struggling with powers beyond their control. Like Lamb (1999: p. 126) puts it "we might wish for a culture in which all aspects of victimization - the strength as well as the vulnerability - would be acceptable". For the basic income system this would mean that benefits receivers should not be made to earn their fundamental rights like they seem to currently be doing. In practice this could mean for example that recipient of basic income benefits could enter a part time job for general amount of time without losing the benefits. If we keep hanging on these twofold either victim or agent solutions in the statute of welfare support we keep losing resources and decrease well-being of many individuals. In the eyes of basic income recipients the bureaucracy is a barrier they are continuously trying to climb over. What would be beyond bureaucracy is a question hard to answer. Maybe equal rights to all humans or complete chaos.

\section{REFERENCES}

Aatola, L., \& Viinisalo, M. (1999). What is the cost of living? Saarijärvi: National Institute for Health and Welfare.

Alvesson, M., \& Karreman, D. (2000). Varietes of discourse: On the study of organizations through discourse analysis. Human Relations, 53, 1125-1149. doi:10.1177/0018726700539002

Autio, M., Wilska, T.-A., Kaartinen, R., \& Lähteenmaa, J. (2009). The use of small instant loans among young adults-A gateway to a consumer insolvency? International Journal of Consumer Studies, 33, 407-415. doi:10.1111/j.1470-6431.2009.00789.x

Bullock, H. (2004). From the front lines of welfare reform: An analysis of social worker and welfare recipient attitudes. The Journal of Social Psychology, 144, 571-588. doi:10.3200/SOCP.144.6.571-590

Cole, A. M. (2007). The cult of true victimhood. From the war on welfare to the war on terror. Stanford, CA: Stanford.

Darbyshire, P., Muir-Cochrane, E., Fereday, J., Jureidini, J., \& Drummond, A. (2006). Engagement with health and social care services: Perceptions of homeless young people with mental health problems. Health and Social Care in the Community, 14, 553-562. doi:10.1111/j.1365-2524.2006.00643.x

Davies, B., \& Harré, R. (1990). Positioning: The discursive production of selves. Journal for the Theory of Social Behaviour, 20, 43-63. doi:10.1111/i.1468-5914.1990.tb00174.x

Dubois, V. (2010). The bureaucrat and the poor. Encounters in French welfare offices. Surrey: Ashgate.

Forma, P., Heikkilä, M., \& Keskitalo, E. (1999). What is the decent minimum? Saarijärvi: National Institute for Health and Welfare.

Fotaki, M. (2011). Towards developing new partnership in public services: Users as consumers, citizens and/or co-producers in health and social care in England and Sweden. Public Administration, 89, 933955. doi:10.1111/j.1467-9299.2010.01879.x

Harré, R., \& van Langenhove, L. (1999). The dynamics of social episodes. In R. T. Harré, \& L. van Langenhove (Eds.), Positioning theory. Moral contexts of intentional action (pp. 1-13). Oxford: Blackwell.

Honkanen, P., \& Tervola, J. (2012). Changes in basic income benefits in 2012. Online working papers 35. Helsinki: The Social Insurance Institution of Finland.

Honkanen, P. (2006). Problems in unemployment allowance. Social security and health research: Working papers 54. Helsinki: The Social Insurance Institution of Finland.

Jost, J. J., \& Levitt, A. J. (2010). Street to home. The experiences of long-term unsheltered homeless individuals in an outreach and housing placement program. Qualitative Social Work, 10, 244-263. doi: $10.1177 / 1473325010369025$

Juhila, K., \& Abrams, L. S. (2011). Special issue editorial: Constructing identities is social work settings. Qualitative Soacial Work, 10, 277 292. doi: $10.1177 / 1473325011409480$

Juntunen, E., Grönlund, H., \& Hiilamo, H. (2006). In the last resort. The Churhc Council of Finnish Ev.Lut.Church. Publications 7. Helsinki: Hakapaino Oy.

Kohm, S. A. (2006). Welfare is the second last resort. The last resort is death. An exploratory analysis of social assistance, victimization and crime. Canadian Journal of Urban Research, 15, 86-108.

Kosunen, V. (1999). How much is enough? Reports. Saarijärvi: National Institute for Health and Welfare.

Kraft, M. K., \& Bush, I. R. (1998). Accountable welfare reform: What consumers think. Public Administration Review, 58, 406-416. doi: $10.2307 / 977550$

Lamb, S. (1999). Constructing the victim. Popular images and lasting labels. In Lamb, \& Sharon (Eds.), New versions of victims. Feminist struggle with the concept (pp. 108-138). New York: New York University Press.

van Langenhove, L., \& Harré, R. (1999). Introducing Positioning Theory. In R. T. Harré, \& L. van Langenhove (Eds.), Positioning theory. Moral contexts of intentional action (pp. 14-31). Oxford: Blackwell.

Lehtinen, A.-R., Varjonen, J., Raijas, A., \& Aalto, K. (2011). What is the cost of living? Reference budgets for a decent minimum standard of living in Finland. Helsinki: National Consumer Research Centre.

Lehto, M. (2009). Proposal of the Committee for reforming social protection (SATA Committee) for the main policylines in the total reform of social protection. Reports 10. Helsinki: Ministry of Social Affairs and Health.

Lipsky, M. (1980). Street-level bureaucracy. Dilemmas of the individuals in public services. New York: Russel Sage Foundation.

Mannheim, K. (1952) The problem of a sociology of knowledge. In K. Mannheim (Ed.), Essays on the sociology of knowledge (pp. 134190). London: Routledge \& Kegan Paul.

Miller, D. L. (2011). Being Called to Account Understanding Adolescents' Narrative Identity Construction in Institutional Contexts. Qualitative Social Work, 10, 311-328.

doi:10.1177/1473325011409479

Minow, M. (1993). Surviving victim talk. UCLA Law Review, 40, 1411-1445.

Mäki, S. (2011). Peruselämää perusturvalla-Taloudellisen niukkuuden kuluttajapositiot.

Peel, M. (2003). The lowest rung. Voices of Australian poverty. Cambridge: Cambridge University Press. doi:10.1017/CBO9780511481581

Pöysä, J. (2010). Positioning narratives. In J. Ruusuvuori, P. Nikander, \& M. Hyvärinen (Eds.), Analysing interviews. Tampere: Vastapaino.

Ronai, C. R. (1999). In the line of sight at public eye. In search of a victim. In S. Lamb (Ed.), New versions of victims. Feminist struggle with the concept (pp. 139-157). New York: New York University Press.

Sakslin, M. (2008). Fundamental rights and reformation of income security. In P. T. Arajärvi, \& R. Särkelä (Eds.), Bread and warmth, perspectives for renewal of social security. SOSTE Finnish Society for Social and Health. Vaajakoski: Gummerus.

Solberg, J. (2011). Activation encounters: Dilemmas of accountability 


\section{S. MÄKI}

in constructing clients as "knowledgeable”. Qualitative Social Work,

10, 381-398. doi:10.1177/1473325011409478

Teater, B. (2010). A qualitative evaluation of the section 8 housing choice voucher program. The recipients' perspectives. Qualitative So- cial Work, 10, 503-519. doi:10.1177/1473325010371242

Virokannas, E. (2011). Identity categorization of motherhood in the context of drug abuse and child welfare services. Qualitative Social Work, 10, 329-345. doi:10.1177/1473325011408480 